\title{
A cat in paradise: hunting and feeding behaviour of Eurasian lynx among abundant naive prey
}

Dula Martin ${ }^{1,2}$ \& Krofel Miha ${ }^{3}$

Corresponding author:martin.dula@mendelu.cz

${ }^{1}$ Department of Forest Ecology, Faculty of Forestry and Wood Technology, Mendel University in Brno, Zemědelská 3, 61300 Brno, Czechia

${ }^{2}$ Faculty of Agrisciences, Mendel University in Brno, Zemědělská 1, 61300 Brno, Czechia

${ }^{3}$ Department of Forestry and Renewable Forest Resources, Biotechnical Faculty, University of Ljubljana, Jamnikarjeva 101, 1000 Ljubljana, Slovenia

\section{Keywords}

Lynx lynx, feeding ecology, parallel kills, predation, kleptoparasitism

\begin{abstract}
Kill rates of predators typically increase when they come into contact with naïve and abundant prey. Such a situation can lead to surplus killing or the occurrence of parallel kills (i.e. additional kills that predator makes while still consuming the carcass from the previous kill). However, there is limited information on the feeding behaviour of predators during such events and how they affect kill rates. Here we report on hunting and feeding behaviour of a male Eurasian lynx (Lynx lynx) that dispersed into a region where this apex predator had been absent for several decades. We also report on the kleptoparasitism by wild boar (Sus scrofa), which effects on lynx prey consumption have not yet been explored. We found 66 ungulates killed by the lynx, among which $39 \%$ were part of parallel kills. Compared to the single kills, lynx fed on parallel kills for 2.7 -times longer, while the kill rate was $37 \%$ higher, resulting in one of the highest kill rates reported so far for male lynx in Europe. We did not detect differences in search times following single or parallel kills and the average distance between consecutive kills was similar in both kill types. We also recorded the highest kleptoparasitism rate by dominant scavengers on Eurasian lynx, as $48 \%$ of kills were usurped and consumed by the wild boars. Kleptoparasitism reduced the average time lynx was able to feed on prey for $52 \%$ compared to kills not found by wild boars. However, the lynx did not compensate for these losses by increasing the hunting effort, probably due to abundant naive prey available in the area.
\end{abstract}


Eurasian lynx (Lynx lynx) is the largest felid in Europe and an important apex predator of wild ungulates in European forest ecosystems (Jędrzejewska and Jędrzejewski, 1998). After killing an ungulate, lynx typically remain at a kill site for several days, until all edible parts of the carcass are consumed, and then move away in search of the next kill (Okarma et al., 1997; Krofel et al., 2013). During the intensive persecution of Eurasian lynx in the previous centuries, the species was completely exterminated from most of Europe (Breitenmoser and Breitenmoser-Würsten, 2008). Following several reintroduction and recovery projects across the continent, the lynx are now recolonising some of the areas, where the species was absent for decades or centuries (Chapron et al., 2014; Mueller et al.; 2020; https://www.lifelynx.eu/; https://snu.rlp.de/de/projekte/luchs/). This could bring lynx in contact with prey that has no experience with this predator (Breitenmoser and Haller, 1993). Such a situation can result in surplus killing of naïve prey, which is generally rare in stable ecosystems (Kruuk, 1972a; Short et al. 2002).

Surplus killing typically refers to events when a predator (or a group of predators) kills several animals during the same hunt, which often results in a low level of utilization of the prey carcasses by the predator (Kruuk, 1972a; Short et al. 2002). Surplus killing is often connected with high prey abundances, including artificial conditions (e.g. poorly protected livestock), or when prey are exposed to exotic or novel predators. Surplus killing of wild or domestic prey has been reported for many carnivores across the world, including felids (Stuart, 1986; McCarthy and Mallon, 2016), canids (Andelt et al., 1980; DelGiudice, 1998), hyaenids (Kruuk, 1972b; Wiesel, 2006), ursids (Reynolds et al., 2002) and mustelids (Oksanen et al., 1985). A similar situation to surplus killing is parallel killing (Jobin et al., 2000), which we define as events when a predator makes additional kills while still consuming the carcass from the previous kill. In this case, the additional kills are not necessarily made during the same hunt when the first kill is made, as is usually the case in surplus killing. But the two processes are similar in predator(s) killing several individuals in a short period and that more prey is killed than needed for immediate satiation of hunger. Parallel killing can be expected especially among the predators that kill large prey and consume it over several days, which is typical for large solitary felids (Krofel et al., 2012).

Here we report on hunting and feeding behaviour of a male Eurasian lynx that dispersed into a region with abundant and naïve ungulates in the Moravian Karst, Czech Republic. We focus on the prey utilization of parallel kills and compare it with the consumption process of single (i.e. non-parallel) kills. Although parallel killing and surplus killings have already been mentioned to occur in lynx predation on wild and domestic prey (Breitenmoser and Haller, 1993; Okarma et al., 1997; Pedersen et al., 1999; Jobin et al., 2000; Odden et al., 2002; Krofel et al., 2006), we lack detailed information on the sequence of lynx feeding in such events and how it compares with feeding behaviour on single kills. We expected that parallel killing would prolong the lynx consumption and prevent predator at be present at all kill sites, which could increase opportunities for large scavengers to usurp the kills. Therefore we also studied the frequency and effects of kleptoparasitism by wild boar (Sus scrofa), which has been noted as an important kleptoparasite for Eurasian lynx in Europe (Jędrzejewski et al., 1993; Jędrzejewska and Jędrzejewski, 1998; Krofel et al., 2012, 2019), but its effects on prey consumption by the lynx remain unexplored.

Eurasian lynx first appeared in the Moravian Karst in autumn of 2016, after several decades of absence (Dul'a et al., 2017). The permanent occurrence of lynx in Moravian Karst and Drahanská Vrchovina Upland was recorded up to the end of the 18th century (Kratochvíl and Vala 1968). After this, only transient lynx from the Carpathians were documented here (Kratochvíl 1968; Červený et al. 1996). The Moravian Karst, situated in Central Moravia, is a 
protected landscape characterised by rugged terrain with deep valleys, steep slopes and numerous karstic phenomena. This human-dominated landscape is a mosaic of beechspruce forests and villages surrounded by arable fields with the average population density of 126 inhabitants $/ \mathrm{km}^{2}$ (Czech Statistical Office, 2017). The most abundant ungulates are roe deer (Capreolus capreolus) and wild boar, followed by mouflon (Ovis musimon) and red deer (Cervus elaphus). The official annual harvest of wild boars, which are also important scavengers in the area, was on average 5.48 wild boar shot per $\mathrm{km}^{2}$ in 2015-2018 (Masaryk Forest Krrtiny Training Forest Enterprise, unpublished data). No permanent presence of large carnivores was recorded in this region before this study (Kutal et al., 2017), but several species of mesocarnivores are present.

The adult lynx male dispersed from Beskydy Mts. (Czech Republic) to Moravian Karst (confirmed by microsatellite genotyping; Krojerová \& Turbáková, personal communication), where he mainly preferred ravine forests and natural rocky habitats (authors' unpublished data). The lynx was captured in a box trap on 15th June, 2017 in the central part of the protected landscape area. The lynx was equipped with GPS/GSM collar (Small WildCell, Lotek Wireless, Newmarket, Ontario, Canada) scheduled to collect a GPS position every 90 minutes for one year (permits for animal capture and handling were obtained from the PLA Moravian Karst Administration and the Czech Ministry of Environment, permit numbers: SR/0081/JM/2017; 34128/ENV/17-2146/630/17). Potential kill sites were identified by location cluster analysis of telemetry data (Krofel et al., 2013) using ArcGIS software (ESRI, and Redlands, CA, USA) and inspected in the field to locate prey remains between 6th of August 2017 and 14th of May 2018. At each kill site, data about sex and age category of prey remains were collected, and if possible, a camera trap was installed to record the feeding behaviour and presence of scavengers (Krofel et al., 2019).

For each kill, the feeding time and search time were calculated (see Krofel et al., 2013 for details). Feeding time was defined as a period between the killing of prey and when lynx abandoned the kill site for the last time (even if the lynx had been using other kill sites inbetween). The search time of the kills was defined as a period between the time when lynx abandoned the given kill and made the next kill. Therefore in the case of parallel killing, the search time for the first of the parallel kills was set as zero value, as lynx made the next kill while still feeding on the previous one. Time of abandonment was defined as the last visit to the given kill site. Time of killing was set in the middle between the last location before and the first location at the kill site, time of prey abandonment was set in the middle between the last GPS location at a kill site and the following GPS location. Visits to a kill site were confirmed when either the lynx GPS position was located within the 50 meters radius around the kills site, or when the lynx presence at the kill site was detected by camera trap footage or lynx tracks in the snow. The annual kill rate (the number of ungulates killed per year) was calculated from the average time interval between the two consecutive kills (i.e. the time between the killing of one and the killing of the next prey). We compared lynx kill rate with the human harvest of ungulates within the 95\% MCP lynx home range $\left(143 \mathrm{~km}^{2}\right)$ as the number of shot ungulates per $1 \mathrm{~km}^{2}$ per year (i.e. average harvest from 2015 to 2018; Masaryk Forest Křtiny Training Forest Enterprise, unpublished data). To compare the average distance between parallel and single kills, we only used data when consecutive kills were of the same type (either both parallel or both single). After checking for normality, the MannWhitney $U$ test was used to test differences in distances between consecutive kills, feeding and foraging behaviour between the single and parallel kills. All statistical analyses were performed using STATISTICA 12 (StatSoft 2013). 
In total, 66 lynx kills were found. All of the killed animals were ungulates, the majority $(74 \%)$ were roe deer and the remaining were mouflon. Lynx killed more females $(66 \%$ of kills, for which we could determine the sex; $n=50)$ and individuals older than one year $(81 \%$ of kills with age determination; $n=63$ ). Eleven parallel kill occasions were recorded, seven of these with two parallel kills and four with three parallel kills (Table 1). Overall, $39 \%$ of kills were part of parallel kills. We recorded the highest number of parallel kills in September, February and March (Fig. 1). All cases of parallel killing comprising three kills occurred between December and February (Table 1; example of the use of such parallel kills provided in animation in the Supp. mat. 1). The average distance between consecutive parallel kills was similar to the distance between consecutive single kills $(5.3 \pm 2.8$ and $5.2 \pm 2.5 \mathrm{~km}$, respectively; $U=364$, $\mathrm{p}=0.87, \mathrm{n}_{\text {parallel }}=15, \mathrm{n}_{\text {single }}=50$ ).

\begin{tabular}{|c|c|c|c|c|}
\hline $\begin{array}{l}\text { Number } \\
\text { of } \\
\text { parallel } \\
\text { kills }\end{array}$ & $\begin{array}{l}\text { Date } \\
\text { (killing of the first kill - } \\
\text { abandonment of the last kill) }\end{array}$ & $\begin{array}{c}\text { Kill identification } \\
\text { (kill } \\
\text { number/species/sex/ag } \\
\text { e category) }\end{array}$ & Feeding sequence & $\begin{array}{l}\text { Feeding } \\
\text { time } \\
\text { (days) }\end{array}$ \\
\hline 2 & Sep 3-Sep 5 & 1-CcUJ, 2-CcFA & 1212 & $1.00,0.94$ \\
\hline 2 & Sep 15-Sep19 & 1-CcFA, 2-OmFA & 121 & $4.00,2.88$ \\
\hline 2 & Sep 23-Sep 27 & 1-CcMA, 2-OmMA & 121 & $3.94,1.38$ \\
\hline 3 & Dec 7-Dec 25 & $\begin{array}{c}\text { 1-CcFA, 2-CcFA, 3- } \\
\text { CcJ }\end{array}$ & 12321 & $\begin{array}{c}18.13,5.25 \\
4.79\end{array}$ \\
\hline 3 & Jan 10-Jan 23 & $\begin{array}{c}\text { 1-CcMA, 2-CcFA, } \\
\text { 3-CcMJ }\end{array}$ & 1212312 & $\begin{array}{c}12.25,8.19, \\
3.13\end{array}$ \\
\hline 3 & Jan 31-Feb 7 & $\begin{array}{c}\text { 1-CcMA, 2-CcFA, } \\
\text { 3-OmFA }\end{array}$ & 12131 & $\begin{array}{c}7.00,1.19 \\
1.74\end{array}$ \\
\hline 3 & Feb 9-Feb 26 & $\begin{array}{c}\text { 1-CcMA, 2-OmFA, } \\
\text { 3-CcMJ }\end{array}$ & $\begin{array}{llllllllll}1 & 2 & 1 & 2 & 1 & 2 & 1 & 3 & 1 & 3\end{array}$ & $\begin{array}{c}13.28,2.19, \\
4.00\end{array}$ \\
\hline 2 & Mar 10-March 14 & 1-СcMA, 2-CcMA & 121 & $3.94,0.13$ \\
\hline 2 & Mar 17-Mar 21 & 1-CcFA, 2-OmFA & $\begin{array}{lllll}12 & 1 & 2 & 1 \\
\end{array}$ & $4.06,1.44$ \\
\hline 2 & Mar 27-Apr 5 & 1-OmFA, 2-CcMA & 121 & $9.19,3.09$ \\
\hline 2 & Apr 30-May 5 & 1-CcMA, 2-OmUJ & 121 & $4.25,0.62$ \\
\hline
\end{tabular}

Table 1: Number, age and sex of ungulates killed by Eurasian lynx as parallel kills and feeding sequences of their consumption. Feeding sequence is provided in respect to the sequential feeding of individual kills (indicated by kill numbers), but note that each number could indicate one or more visits to the same kill (i.e. only switches from feeding at one to another kill are indicated). Feeding times correspond to the time between the killing and the last visit to each of the kills in the series (in the same order as in Kill identification). Cc - Capreolus capreolus, Om - Ovis musimon, F - female, M male, $\mathrm{U}$ - unknown, $\mathrm{J}$ - juvenile, A- yearling/adult.

For all kills, the average feeding time was $2.9 \pm 3.3$ days (min: 0.1 , max: 18.1), the average search time was $1.9 \pm 1.9$ day (min: 0.0 , max: 8.7 ), and the average interval between the kills was $4.3 \pm 2.5$ days (min: 0.3 , max: 12.8 ). The average annual kill rate was estimated to 84.7 ungulate kills per year (62.9 roe deer and 21.8 mouflon) and 0.83 ungulate $/ \mathrm{km}^{2}$ ( 0.61 roe deer $/ \mathrm{km}^{2}$ and 0.21 mouflon $/ \mathrm{km}^{2}$ ). This is $34 \%$ and $23 \%$ compared to the official human harvest (1.8 roe deer and 0.92 mouflon shot per $1 \mathrm{~km}^{2}$ per year) inside the home range of the monitored lynx. The lynx spent considerably more time feeding on the parallel ( $4.7 \pm 4.3$ days) than on the single kills $\left(1.7 \pm 1.5\right.$ days; $\left.U=254, p=<0.001, n_{\text {parallel }}=26, n_{\text {single }}=40\right)$. Search time was somewhat longer after the parallel kills $(3.1 \pm 2.4$ days) compared to search time following single kills (2.4 \pm 1.6 days), but the difference was not statistically significant $(U=171, p=0.31$, $\left.n_{\text {parallel }}=11, n_{\text {single }}=39\right)$. The interval between the kills was significantly shorter between the 
parallel kills (3.0 \pm 2.0 days) than between single kills (4.7 \pm 2.5 days; $U=216, p=0.01$, $\left.\mathrm{n}_{\text {parallel }}=15, \mathrm{n}_{\text {single }}=50\right)$.

Relatively high level of kleptoparasitism by wild boars on lynx kills was recorded (examples are provided in videos in the Supp. mat. 2). We were able to assess the presence of scavengers at 50 lynx kill sites, and among them, $48 \%$ were usurped and consumed by wild boars. The proportion of kleptoparasited kills was lower for parallel $(26 \%, n=19)$ than single kills $(61 \%, n=31)$. Feeding time of the lynx was reduced for $52 \%$ at kills usurped by the wild boar ( $1.2 \pm 1.3$ days; $n=24$ ) in comparison to kills not found by the wild boars ( $3.8 \pm 4.0$ days, $\mathrm{n}=26 ; \mathrm{U}=204.5, \mathrm{p}=0.03$ ). Search time and inter-kill interval after kills usurped by wild boar and those without wild boar presence were similar (search time, with wild boar: $1.9 \pm 1.4$ days, $\mathrm{n}=24$; without wild boar: $2.09 \pm 2.3$ days, $n=26$; $U=293, p=0.71$; interval between the kills, with wild boar: $4.6 \pm 2.3$ days, $n=24$; without wild boar: $4.6 \pm 2.6$ days, $n=26 ; U=294, p=0.73$ ). This indicates that lynx did not compensate for losses due to boar kleptoparasitism by increasing the hunting effort.

Our results obtained from Moravian Karst provide the first detailed insight into lynx feeding behaviour when utilizing parallel kills, which differs from single kills in longer feeding time and shorter interval between kills. When predators are killing one prey after another (i.e. single kills), the longer feeding time usually results in longer inter-kill intervals. However, we showed that this is no longer true when the predator is making parallel kills because of simultaneous feeding on several kills. Shorter inter-kill intervals result in higher predation pressure on prey populations and the kill rate documented in our study (corresponding to 85 ungulates killed annually) represents the highest recorded rate for adult male lynx across all populations studied so far in Europe (e.g. Breitenmoser and Haller, 1993; Okarma et al., 1997; Jobin et al., 2000; Gervasi et al., 2013; Krofel et al., 2014; Andrén and Liberg, 2015; Belotti et al., 2015). However, our results presented here need to be treated with caution, as they are limited to a single individual and may thus not be representative for lynx in general, given the potential for individual variability. Nevertheless, it provides an insight into a possible scenario after recolonization of an area where lynx have been absent for a long period. It also demonstrated the need for more research focus on the phenomenon of parallel killing.

A similar situation was reported for Eurasian lynx by Breitenmoser and Haller (1993) who documented the expansion of the reintroduced lynx population in Switzerland and noted several cases of parallel killing in the newly colonised areas at the population expansion front. Occasional anecdotal records of parallel killing on wild or semi-wild ungulates have also been reported from areas with established lynx populations, indicating that it is not limited to areas with naïve prey (Okarma et al., 1997; Pedersen et al., 1999; Jobin et al., 2000; Kutal, 2004; Krofel et al., 2006). However, none of these studies reported such a high frequency of parallel killing as we detected in Moravian Karst (almost $40 \%$ of all kills), which we suggest to be primarily connected with the high abundance of ungulates and lack of previous experience with large predators by the prey.

We recorded all cases of parallel killing comprising of three kills during the winter period (Table 1) and we observed an increasing trend in the occurrence of parallel killing from December to March, which increased simultaneously with the activity and average daily distance moved by the male lynx, possibly reflecting the change in behaviour due to the mating period (Fig. 1). Additionally, freezing temperatures and snow cover keep prey remains fresh and useable for a longer period (Ray et al., 2014), which might have enabled lynx to prolong the use in the winter period, possibly contributing to the higher occurrence of parallel killing. 


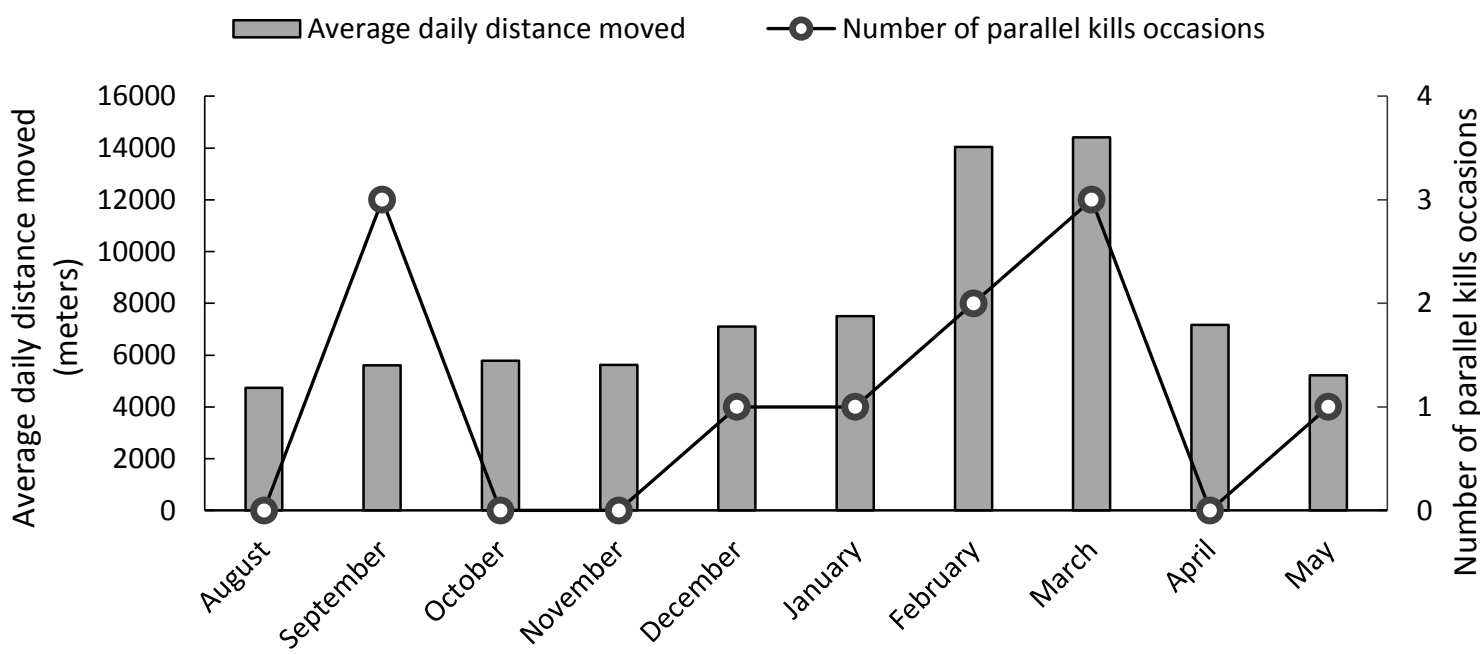

Fig 1: Occurrence of parallel killing occasions per month in combination with the average daily distance moved by the lynx in the study period (6 August 2017-14 May 2018). Data are shown according to the average date of the killings in the series of parallel kills.

Longer feeding times of the parallel kills compared to single kills, in general, make lynx more susceptible to kleptoparasitism. Therefore we expected that scavengers would usurp more carcasses belonging to the parallel kills than single kills, but the opposite pattern was observed. Possible explanation could be connected with a higher frequency of parallel killing during the winter period, when detection of carcasses by the scavengers could be reduced by slower decomposition and fainter smell of carrion.

In our study area, the most important scavenger was the wild boar, which we recorded at almost half of the lynx kills. This is much higher compared to the losses to wild boar in Dinaric Mountains (2-8\%; Krofel et al. 2012, 2019) and even higher than the $40 \%$ frequency reported from Bialowieza in Poland (Jędrzejewski et al., 1993, Jędrzejewska and Jędrzejewski, 1998). For the first time we were able to also estimate the effects of wild boar kleptoparasitism on lynx prey consumption, which resulted in considerable $(52 \%)$ reduction of the feeding time (which could be used as a proxy for consumed biomass; Krofel et al., 2012). This is comparable to the high rate of reduced feeding opportunities for lynx $(47 \%$ shorter feeding times) documented as a consequence of kleptoparasitism by brown bears (Ursus arctos) in the Dinaric Mountains (Krofel et al., 2012). However, in contrast to the bear kleptoparasitism, lynx in Moravian Karst did not respond to losses due to scavenging wild boars by increasing the kill rate. We assume that this could be connected with higher availability of naïve prey in our study area and shorter search time required to make the next kill, as well as frequent parallel killing (in Dinaric Mountains lynx are present already since the 1970s, have longer search times and rarely make parallel kills; Krofel et al., 2006, 2013). This likely provided lynx in Moravian Karst with ample food, which made losses to scavengers less important, despite the highest kleptoparasitism rate by dominant scavengers reported so far for Eurasian lynx (reviewed in Krofel et al. 2012).

Information presented in this study will likely become increasingly important in the future when recovering and reintroduced lynx populations are expected to recolonise several areas with abundant and naïve prey, where large predators have been absent for several decades or even centuries. As demonstrated here and in the previous study (Breitenmoser and Haller, 1993), this can result in high predation pressure, especially when lynx succeeds in making parallel kills. However, such high predation pressure is expected to be limited to a relatively 
short period, as eventually prey respond to the new predator with re-establishment of antipredator behaviours, which can lead to the increase of predator home range sizes that in turn decrease the predation rates (Breitenmoser and Haller, 1993).

\section{Acknowledgements}

We would like to express our gratitude to M. Daněk, A.Krása, Č. Šnoblt, R. Mezera, D. Franc, A. Ždánský and other volunteers for their help collecting data, and L. Purchart, M. Kutal and K. Uherková for scientific background and project coordination. For assistance with animal capture and use of equipment, we would like to thank P. Forejtek, J. Krojerová-Prokešová, M. Slamka, P. Kaštier and M. Kalaš. We are also grateful to the Nature Conservation Agency of the Czech Republic PLA Administration Moravian karst, Training Forest Enterprise Masaryk Forest Kritiny, Institute of Vertebrate Biology Czech Academy of Sciences, National Forest Centre in Zvolen and the Ministry of the Environment of the Czech Republic for cooperation and project support. We are also grateful to T. Oliveira for making the animation of lynx movement. This study was partly financed by the Dean's office of the Faculty of Forestry and Wood Technology, Mendel University in Brno and Training Forest Enterprise Masaryk Forest Kritiny. M.D was supported by the Erasmus+ programme for the traineeship held at Department of Forestry and Renewable forest resources, Biotechnical Faculty, University of Ljubljana. M.K. was supported by the Slovenian Research Agency (grant P4-0059).

Conflict of interest

On behalf of all authors, the corresponding author states that there is no conflict of interest.

\section{References}

Andelt WE, Palthoff D, Case RM, Gipson PS (1980) Surplus killing by coyotes. Journal of Mammalogy 61, 377-378. https://doi.org/10.2307/1380076

Andrén H, Liberg $\mathrm{O}$ (2015) Large impact of Eurasian lynx predation on roe deer population dynamics. PLoS ONE 10, e0120570. https://doi.org/10.1371/journal.pone.0120570

Belotti E., Weder N., Bufka L., Kaldhusdal A., Küchenhoff H., Seibold H., Woelfing B., Heurich M., (2015) Patterns of Lynx Predation at the Interface between Protected Areas and Multi-Use Landscapes in Central Europe. PLoS ONE 10, e0138139.

https://doi.org/10.1371/journal.pone.0138139

Breitenmoser U, Breitenmoser-Würsten C (2008) Der Luchs: Ein Grossraubtier in der Kulturlandschaft. Salm Verlag, Wohlen and Bern.

Breitenmoser U, Haller H (1993) Patterns of predation by reintroduced European lynx in the Swiss Alps. Journal of Wildlife Management 57, 135-144.

Červený J, Koubek P, Anděra M (1996) Population development and recent distribution of the lynx (Lynx lynx) in the Czech Republic. Acta Scientiarum Naturalium Academiae Scientiarum Bohemicae 30, 2-15.

Chapron G, Kaczensky P, Linnell JDC, von Arx M, Huber D, Andrén H, López-Bao JV, Adamec M, Álvares F, Anders O, Balčiauskas L, Balys V, Bedő P, Bego F, Blanco JC, Breitenmoser U, Brøseth H, Bufka L, Bunikyte R, Ciucci P, Dutsov A, Engleder T, Fuxjäger C, Groff C, Holmala K, Hoxha B, Iliopoulos Y, lonescu O, Jeremić J, Jerina K, Kluth G, Knauer F, Kojola I, Kos I, Krofel M, Kubala J, Kunovac S, Kusak J, Kutal M, Liberg O, Majić A, Männil P, Manz R, Marboutin E, Marucco F, Melovski D, Mersini K, Mertzanis Y, Mysłajek RW, Nowak S, Odden J, Ozolins J, Palomero G, Paunović M, Persson J, Potočnik H, 
Quenette PY, Rauer G, Reinhardt I, Rigg R, Ryser A, Salvatori V, Skrbinšek T, Stojanov A, Swenson JE, Szemethy L, Trajçe A, Tsingarska-Sedefcheva E, Váňa M, Veeroja R, Wabakken P, Wölfl M, Wölfl S, Zimmermann F, Zlatanova D, Boitani L (2014) Recovery of large carnivores in Europe's modern human-dominated landscapes. Science 346, 15171519.

Czech Statistical Office, Regional Office of the Czech Statistical Office in Brno (2017) Statistical yearbook of the Jihomoravsky region. https://www.czso.cz/csu/czso/statistickarocenka-jihomoravskeho-kraje-2017. Accessed 1 Mar 2020

DelGiudice GD (1998) Surplus Killing of White-Tailed Deer by Wolves in Northcentral Minnesota, Journal of Mammalogy 79, 227-235. https://doi.org/10.2307/1382858

Dula M, Jelínek P, Kutal M (2017) Rys v Moravském krasu. Veronica 31, 35. (In Czech)

Gervasi V, Nilsen EBE, Odden J, Bouyer Y, Linnell JDC (2013) The spatio-temporal distribution of wild and domestic ungulates modulates lynx kill rates in a multi-use landscape. Journal of Zoology 292, 9. https://doi.org/10.1111/jzo.12088

Jędrzejewska B, Jędrzejewski W (1998) Predation in vertebrate communities: the Białowieża Primeval Forest as a case study. Springer, Heidelberg

Jędrzejewski W, Schmidt K, Milkowski L, Jędrzejewska B, Okarma H (1993) Foraging by lynx and its role in ungulate mortality - the local (Białowieża Forest) and the Palearctic viewpoints. Acta Theriologica 38, 385-403.

Jobin A, Molinari P, Breitenmoser U (2000) Prey spectrum, prey preference and consumption rates of Eurasian lynx in the Swiss Jura Mountains. Acta Theriologica 45, 243-252.

Kratochvíl J (1968) Changes in the distribution of the Lynx and its Protection in Czechoslovakia. Recent distribution of the lynx in Europe. Acta Sciences of Nature Brno 2, 316.

Kratochvíl J Vala F (1968) History of Occurrence of the Lynx in Bohemia and Moravia. History of the distribution of the Eurasian lynx in Europe. Acta Sciences of Nature Brno 2, 3546.

Krofel M, Jerina K, Kljun F, Kos I, Potočnik H, Ražen N, Zor P, Žagar A (2014) Comparing patterns of human harvest and predation by Eurasian lynx Lynx lynx on European roe deer Capreolus capreolus in a temperate forest. European Journal of Wildlife Research 60, 1121. https://doi.org/10.1007/s10344-013-0745-4

Krofel M, Kos I, Jerina K (2012) The noble cats and the big bad scavengers: effects of dominant scavengers on solitary predators. Behavioral Ecology and Sociobiology; 66: 12971304. https://doi.org/10.1007/s00265-012-1384-6

Krofel M, Potočnik H, Skrbinšek T, Kos I (2006) Movement and predation patterns of Eurasian lynx (Lynx lynx) on Menišija and Logatec plateau (Slovenia). Veterinarske novice 32, 11-17. (In Slovenian)

Krofel M, Skrbinšek T, Kos I (2013) Use of GPS location clusters analysis to study predation, feeding, and maternal behavior of the Eurasian lynx. Ecol Res 28, 103-116.

https://doi.org/10.1007/s11284-012-1005-x 
Krofel M, Skrbinšek T, Mohorović, M, (2019) Using video surveillance to monitor feeding behaviour and kleptoparasitism at Eurasian lynx kill sites. Folia Zool 68, 55-65.

Kruuk H (1972a) Surplus killing by carnivores. J Zool 166, 233-244.

Kruuk H (1972b) The spotted hyena: a study of predation and social behavior. The University of Chicago Press, Chicago.

Kutal M (2014) Ekologie rysa ostrovida (Lynx lynx) a vlka obecného (Canis lupus) v oblasti Západních Karpat a jejich význam v lesním ekosystému. Dizertační práce, Mendelova univerzita, Brno, 140 pp. (In Czech)

Kutal M, Belotti E, Volfová J, Mináriková T, et al. (2017) Výskyt velkých šelem - rysa ostrovida (Lynx lynx), vlka obecného (Canis lupus) a medvěda hnědého (Ursus arctos) - a kočky divoké (Felis silvestris) v České republice a na západním Slovensku v letech 20122016 (Carnivora). Lynx n.s. 48, 93-107. (In Czech).

McCarthy, T., Mallon, D., 2016. Snow Leopards. Academic Press, London.

Mueller SA, Reiners TE, Middelhoff TL, Anders O, Kasperkiewicz A, Nowak C (2020) The rise of a large carnivore population in Central Europe: genetic evaluation of lynx reintroduction in the Harz Mountains. Conserv Genet 21, 577-587. https://doi.org/10.1007/s10592-020-01270-w

Odden J, Linnell JDC, Moa PF, Herfindal I, Kvam T, Andersen R (2002) Lynx predation on domestic sheep in Norway. J Wildl Manag 66:98-105

Okarma H, Jędrzejewski W, Schmidt K, Kowalczyk R Jędrzejewska B (1997) Predation of Eurasian lynx on roe deer and red deer in Bialowieza Primeval Forest, Poland. Acta Theriologica 42, 203-224.

Oksanen T, Oksanen L, Fretwell SD (1985) Surplus killing in the hunting strategy of small predators. Am Nat 126, 328-346.

Pedersen V, Linnell JDC, Andersen R, Andrén H, Segerström P, Lindén M (1999) Winter lynx predation on semi-domestic reindeer in northern Sweden. Wildl Biol 5:203-212

Ray RR, Seibold H, Heurich M (2014) Invertebrates outcompete vertebrate facultative scavengers in simulated lynx kills in the Bavarian Forest National Park, Germany. Animal Biodiversity and Conservation 37, 77-88.

Reynolds P, Reynolds H, Shideler R (2002) Predation and Multiple Kills of Muskoxen by Grizzly Bears. Ursus 13, 79-84.

Short J, Kinnear JE, Robley A (2002) Surplus killing by introduced predators in Australiaevidence for ineffective anti-predator adaptations in native prey species? Biol Conserv 103, 283-301. https://doi.org/10.1016/S0006-3207(01)00139-2

StatSoft, Inc. (2013) STATISTICA (data analysis software system), version 12. www.statsoft.com. Accessed 12 Jan 2019

Stuart CT (1986) The Incidence of Surplus Killing by Panthera pardus and Felis caracal in Cape Province, South-Africa. Mammalia 50, 556-558. 
Wiesel I (2006) Predatory and Foraging Behaviour of Brown Hyenas (Parahyaena brunnea (Thunberg, 1820)) at Cape Fur Seal (Arctocephalus pusillus pusillus Schreber, 1776)

Colonies. PhD Thesis, University of Hamburg, Germany.

\section{Electronic supplementary material}

\section{Supplementary material 1 Examples of using parallel kills by the Eurasian lynx}

\section{Supplementary material 2 Examples of wild boar kleptoparasitism on Eurasian lynx kills}

Description of the video: Two examples of kleptoparasitism by wild boars on male Eurasian lynx recorded with an automatic camera in the Moravian Karst, Czechia. In the first part, wild boars usurped and consumed carcass of a young male mouflon that was killed by lynx 2 days before the recording. The wild boars found and partly consumed the carcass already before the cameras were set up. After deployment of cameras, wild boar returned for another 31 min of eating, after which only non-edible remains of carcass were left when the lynx returned. In the second part, wild boars and lynx were present simultaneously at the vicinity of a kill site with remains of female roe deer. After the encounter, lynx was recorded at the kill site, but only for a couple of seconds and then abandon the carcass. After this, the carcass was completely consumed by the wild boars. 